\title{
Examining the Effect of Project Delays in Construction Field, A Case Study of Prime Engineering and Service Ghana Limited
}

\author{
Prince Kelvin Owusu ${ }^{1} \&$ Daniel Ekow Gyasi Aggrey ${ }^{2}$ \\ ${ }^{l}$ Information Systems Department, Ghana Communication Technology University, Ghana. \\ ${ }^{2}$ Department of Project Management, Prime Infrastructure and Engineering Services Ghana Limited, Ghana.

\section{ABSTRACT}

The alarming rate of project delays in this country needs urgent attention and resolution as one project delay leads to another therefore affecting the growth of any economy or profit-making organization. This alarming rate would possibly go out of one's hand if strategies are not put in place to curb these phenomena. The Objectives of this research is to critically identify and evaluate the setbacks or factors causing delays in completing projects on time and its effect. The study narrowed its arrows on Prime Ghana projects executed in the country and it was thus conducted with the usage of questionnaires to solicit for the required data for processing. Results from the study divulge that the actual sources of delays in project delivery are Inadequate financial resources of clients, delays in honoring payment for work done, underestimation of project duration, poor communication between contracting parties, complexity, difficulties in accessing bank credit (client); change orders during construction and others. It was recommended that, initial proper planning and controlling is essential to the client to have proper action plan, procurement plan, and budget plan prepared before commencement of project. Payment schedule must be agreed by the parties involved. On the part of the contractor adequate knowledge of project management, principles, tools and techniques is required to reduce delays. Consultants must plan very well to ensure that contract processes are duly followed, thus approval of drawings, documentation, and other things to reduce variation during construction. They should monitor their assigned work very well by insisting that corrections are done at the appropriate time to reduce or avoid rework.

Keywords: Project management, Project delays, Delay effects, Construction industries, Engineering project.

\section{Introduction}

The cumulative demand for construction works in the Ghanaian domain indicates the relevance of the industry's contribution to the country's social economic development. Politicians and policymakers tout large-scale construction to stimulate economic growth and generate employment (Amoatey et al., 2015; Joshi and Khan, 2010). Rapidly urbanizing emerging markets with mass housing programs have experienced relatively strong economic growth, such as Singapore and Hong Kong (Bredenoord and van Lindert, 2010; Arku, 2006; Mayo and

Sheppard, 1996; Pugh, 1987).

Over the years these delays have been noticed by the Ghanaian populace and written off any sort of attention to the completion of projects handled even by Government of Ghana (GoG) official and has cupped it in their minds to election year where as it was; projects are seen to be crushed just so that votes could be worn. This cultural or behavior thinking transcends into our way of life and gradually found its bearing in the way we manage projects in the county. The Construction industry faces the plague of failures in project timely closures. Mohammed (2015), argued that construction delay designates prolonged period of construction caused by interruption of proceedings.

In the view of Bakr (2015), the main causes of project delays are caused by project scope; planning deficiencies; unavailability of risk management system; unavailability of resources; inaccurate project estimates and task assessment; and delay in drawing and approving project designs. The factors that may result in a change of project scope and thereby causing construction delay may include errors in design and scope addition (Jaber, 2015). Ineffective planning at the bidding stage leads to increasing costs. Due to Lack of effective planning, realistic schedules are not achieved. Moreover, there is decrease productivity and thereby leading to project delay (Al-Agele and Hassan, 2016). According to $\mathrm{Zu}$ et al. (2018), delays also occur resulting in project delay effective time 
management and communication. The workers work for long hours and thereby contributing to project delay. In accurate task assessment results in an unreliable estimate and thereby leading to project delays. It may also make project cost very high to their owners. In the view of Tripathi and Jha (2018), project delay has effect on total project abandonment. Wu et al (2018) established that project abandonment of project occurs when the contractor is unable to undertake the project within a reasonable time frame as agreed with the customer. According to Aziz and Abdel-Hakam (2016), time overrun occurs because contractors are not able to complete the project scope on the agreed timelines which has been identified as one of the effects of project delays. Cost overrun has been found to be one of the roots of construction delay in Ghana (Wu et al.,2009). Cost overrun refers to the overtime cost incurred whenever construction projects are delayed and thereby leading to the time for completion of project being delayed. Litigation is also one of the consequences of construction delay (Al-Agele and Al-Hassan, 2016).

According to Kumar (2016), delayed projects have led to infrastructure gap in areas such as roads, water, bridges, electricity, hospitals, and sanitation. In the view of Wu et al. (2018), project delay has effect on total project abandonment. Mohammed (2015) revealed that project abandonment is where contractor will not be able to perform the contract due to the contractor's inability to start the project within a reasonable amount of time. Time overrun which is caused when the contractor is unable to complete the project within the time frame is also one of the effects of projects (Jaber, 2015). One of the effects of construction delay is cost overrun in Ghana (Kumar, 2016). In the view of Bakr (2015), cost overrun refers to the overtime cost incurred whenever there is construction delay there is the scheduled time for completion of project. Litigation was construction delay consequences. To avoid the harmful effect of construction delay there is the need to manage construction delays (Wu et al., 2018). In the view of Jaber (2015), project management principles which are the fundamental rules that should be observed in managing project delays. Managing planning and scheduling which are ineffective are ways of managing construction delays. Managing staff qualification, skill and experience helps prevent construction delay to avoid contraction project delay is a way of managing project delay (Bentil, 2014). one of the ways of managing construction delay is to change order during construction as a way of managing construction delays. To lessen the issues causing unwanted delay in construction projects, there should be the introduction of change orders to curb these occurrences. Project management principle is used to managing change order (Aziz and Abdel-Hakam, 2016). Delay rectification is also a way of managing construction delays. Despite these numerous ways of managing the inefficient way of managing construction delay, much have not been done when it comes to Ghana in terms of literature. Studies undertaken in projects delay in Ghana only concentrated on the causes of project delay. This study therefore aims at filling the gap and goes on to further examine the effect of delays in the construction field.

\section{Literature Review}

\section{A. Definition of Project Delay}

Delay and cost overrun have become part of most projects notwithstanding the considerable assimilated knowledge in project management. Though some may argue that this is insignificant yet it is imperative to take into cognizance that physical and economical scales of projects currently is such that it is motivated under the platform of profit to 
the parental organization, and of a national interest, as well-defined within the Iron triangle of cost, time, and scope. Consequently, it is esteemed to look at some motivations of delays and cost overrun in project and their extenuation procedure, to bring growth in the perception of project success. In the view of Mohammed (2015), Construction delay refers to prolonged period of construction caused by interruption of events.

In the view of Bakr (2015), the main causes of project delays are caused by project scope; planning deficiencies; unavailability of risk management system; unavailability of resources; inaccurate project estimates and task assessment; and delay in drawing and approving project designs.

\section{B. Managing delays in construction projects}

According to Bakr (2015), construction projects are known to be amongst the most occurring problem faced by the industry. This sprouts negatively impact on both parties involved in the project itself. The main causes of these delays should be pinpointed to work on reducing and eradicating them as well as matching outlays (Al-Agele et al., 2016). According to $\mathrm{Wu}$ et al (2018), construction projects continue to face the challenge of delays even in this current phase of knowledge in technology as well as organization management. Aziz and Abdel-Hakam (2016) stated that, delay in the setting of construction refers to a project happening later than the anticipated time specified in terms and conditions of the contract or exceeding the date set by parties involved.

According to Alsuliman (2019), when project is delayed, they are either giving time extension or the project activities augmented or thus causing extra cost. Even though parties involved in the project would agree up on the additional cost and time that are related with the delay, in most cases problems exist between the contractors and the clients as regards whether a contractor has the right to claim for extra cost (Abdel-Hakam, 2016). Wu et al (2018) stated that, countries are assessed as underdeveloped, developed, and developing based on quality and quantity of accomplished construction projects inside their territory. Bakr (2015) established that, many researchers have carried out a number of studies concerning the factors that causes delays as well as cost overruns and their effects on output, quality, and safety form the common problems in some project types.

According to (Al-Agele et al., 2016), a project's success or failure, which is for commercial construction projects, it depends largely on the schedule of the project and whether that schedule is reality and is attainable. Delays that pertain to construction schedule have negative impact on both the contractors and the 11 owners to the extent that delays cause owners to absorb or pay additional cost and still are not able to use or occupy their property for it intended purpose (Jung and Han, 2017).

Several attempts by researchers as well as project professionals to tackle the effect and causes of delays in construction project have not met the positive results needed as Asadi et al. (2018) suggests. Guo et al (2018) concluded on his study conducted in Ankara Turkey that, delay could occur in the preconstruction stage described as the beginning to the stage of contract signing between the client and the contractor, but many construction projects delay in the stage of the construction. Al-Agele et al. (2016) also said industry of construction is one that involves dynamic and complex process. Delays in construction are usually experienced in the public sector but at times too in the private sector as well according to Guo et al (2018). 


\section{Contractor associated causes of project delay}

Contractor related causes of project delay can contribute to project delay. In the view of Kamandang et al. (2017) contractors can also contribute to project delay. Material management if not properly taken care of would lead to project delay particularly in of construction. According to Kusakci et al. (2017), contractor related factors that causes completion delays includes poor planning. In the view of Sezgin and Asarkaya (2017), when the contractors of the projects are unable to allocate sufficient funds to the various stages of construction, it may lead to construction delay. Secondly, inappropriate scheduling can lead to project delay: Poor quality of materials may lead to project delay because the usage of poor-quality materials at sites can lead to shoddy work or reworks as it will not meet the project quality KPIs. There should be availability of equipment for projects. Equipment is needed to facilitate the successful execution of construction projects. However, unavailability of the needed equipment can lead to project delay. The contractors' slow decision making can affect project delay. This implies that if the contractors do not make quick decisions it may lead to delay in projects.

\section{Design related causes of delay}

Kusakci et al. (2017) established that poor design management can affect construction delay. Incomplete drawings can lead to delay in construction delay. The time used in Designing changes and modification in construction can lead to construction delay. Design errors can also lead to construction delay. In view of the fact time is needed to rectify design errors, construction may be delayed (Sezgin and Asarkaya (2017). Structures do not build on right design may lead to demolition and reworks which would increase the timelines of the project.

\section{Labour related causes}

Labour related causes of project delay can contribute to project delay. In the view of Adams et al. (2017) labour can contribute to project delay. Low workers' morale can lead to project delay particularly in construction. Unsatisfactory compensation affects workers morale. Poor working conditions affect projects and thereby leading to project delays. Contractors are unable attract personnel with the requisite technical competencies to facilitate projects. According to Tripathi and Jha (2018), labour related factors include strikes and poor workmanship. In the view of Amoatey et al. (2015) shortage of workers and technical personnel can lead to project delay. Low productivity affects project delay.

\section{Weather Conditions}

According to Amoatey et al. (2015), harsh weather conditions can contribute to project delay. Unforeseen grounds conditions can contribute project delay. Harsh weather conditions can affect the supply of materials needed for the execution of projects. Inability to provide the materials for construction can affect construction delay (Tripathi and Jha, 2018).

\section{Contractor's financial difficulties}

Adams et al. (2017) established that contractor's financial difficulty is one of the factors which affect project delays. Contractor's financial difficulty includes the contractor's inability to pay his/her indebtedness when they 
Asian Journal of Applied Science and Technology Volume 4, Issue 3, Pages 129-144, July-September 2020

fall due (Kusakci et al., 2017). When contractors are in financial difficulties, they are unable to pay for cost of materials; pay the salaries of their staff and acquire equipment for the execution of projects. Clients' inability to pay their contractors leads contractors into financial difficulties.

\section{Material Shortage}

Unreliable suppliers lead to material shortage which leads to project delays. Unreliable suppliers do not supply materials to contractors within the stipulated time. Failure to supply within the time schedule can contribute to material shortage (Kusakci et al., 2017).

Poor communication can contribute to material shortage. Inability to communicate well affects projects. Ineffective communication between the contractor and the suppliers can lead to material shortage and wrong specifications delivered, this increases the time of completion as it directly affects the stipulated completion time.

\section{Theoretical Framework}

The underpinning theories for project delays are organisational theory, agency theory and financial distress.

\section{Organizational theory}

Organizational theory centre's on bureaucracies and social organisation and their association with the environment (Guo et al., 2018).

The organizational theory aims at achieving efficiency. Nguyen (2019) describes the decision-making process in the organisation. In organisational theory social units of people are structured and managed to meet their needs.

\section{Agency Theory}

Agency theory involves contractual relationship between stakeholders namely employees, managers; employees etc ( $\mathrm{Su}, 2018)$. Agency theory is concerned with problems caused through contractual conflicts. In agency theory there is conflict between partners due to different subject interest. Disagreement may arise due to disagreement between contracting parties. This conflict contributes to contractual parties undertaking actions which may not be in the interest of other contracting parties.

\section{Financial Distress Theory}

In financial distress theory looks at factors which contribute to decline in firm's performance.

Su et al. (2018) revealed that financial distress factors involve inability of organisation to honour its financial obligation when they fall due. In view of the fact that there is pay out distribution association, there is the need to assess the probability of organisations financial distress. It must be emphasised that investment decisions and financing are in separable. Organisations should hold their balance sheet on debts and equity claim as one.

\section{E. Effects of Delays}

According to Mahamid (2017), 0n the impact of construction delays in the industry of construction include: total abandonment; Time overrun; Cost overrun; and Litigation. 


\section{Total Abandonment}

Project abandonment is where the contractor stops the project. Project abandonment occurs when the contractor does not start within a reasonable amount of time. Causes of abandoned construction projects are categorized into five. They include namely government policies; public delivery system; economic conditions; mismanagement and financial problems. According to Oyegoke et al. (2017), projects with poor costing are more likely to be abandoned. Mahamid (2017) also established that projects which have no starting and ending points. In the view of Oyegoke et al. (2017), factors contributing to project abandonment embrace over ambitious projects etc.

\section{Time Overrun}

Time overrun is an effect of construction delay. Fiscal challenges and payment of work completed. in the view of Nyuyen (2019), the factors contributing to time overrun also include contract mismanagement, site situation and inadequate planning.

\section{Cost Overrun}

In construction projects there is cost overrun. Cost overrun refers to increase in project cost (Mpofu et al., 2017). Reworking contributes to cost overrun. Construction mistake can be corrected by incurring more cost. About 15\% of construction work is the costs incurred as construction overrun (Bekr, 2015).

\section{Litigation}

One of the effects of construction delay is Litigation. In the view of Ruqaishi and Bashir (2015), when the arbitration does not work, the court system administers justice. According to Owolabi and Olusanya (2014), consultants and contractors are responsible for litigation. According to Ruqaishi and Bashir (2015), ranked litigation as the four most effect of construction delay.

\section{F. Conceptual Framework}

The conceptual framework comprised one dependent variable and four independent variables.

Flow management

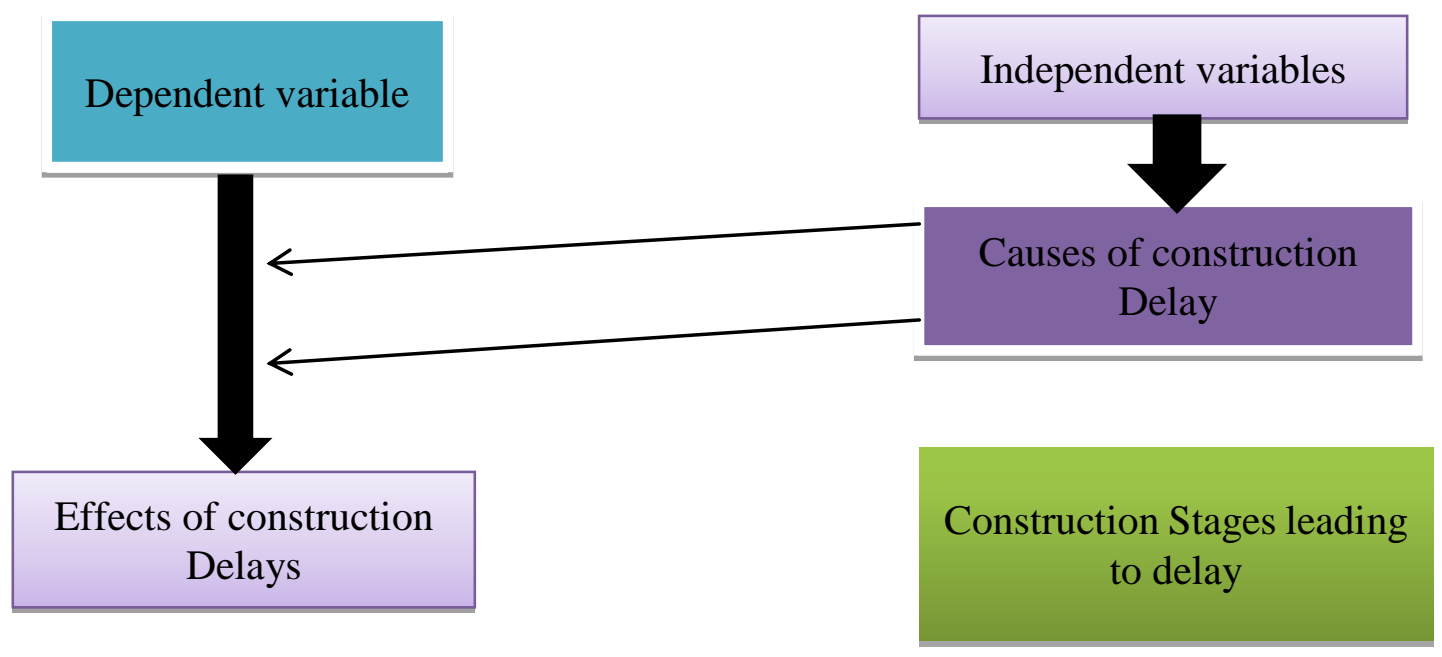

Fig.1 Conceptual framework (Authors' Design, 2020) 


\section{Independent Variable}

\section{Causes of delay in projects}

Causes of construction Delay includes but not limited to project scope not being reasonable; in adequate or in sufficient planner; lack of risk management system; inadequate resources; task assessment not been accurate; task lacking clarity and approval.

\section{Construction Stages leading to delay}

Construction Stages leading to delay includes feasibility study phrase; the design phrase; contracting phrase; implementing phrase; delivery phrase and investment (operation) phrase.

\section{Dependent Variable}

\section{Effects of construction Delays}

Effects of construction delays include Total Abandonment; ligation; and time and cost overrun.

How to manage construction delays

\section{Project management principles}

Construction delays may be managed through project management principles. Managing projects involves, organizing; planning; securing; controlling resources for specific goal achievement. Managing projects involves fundamental rules which are observed for managing projects successfully. They include structures involved in project management; Goals and outcomes; rules being documented. The key factors causing construction delays include, ineffectual scheduling and planning of the construction plan (Kim et al., 2016).

\section{Methodology}

\section{A. Research Design}

In the opinion of Atkinso et al. (2016), Research Design refers to the overall strategy adopted to integrate different components of the study with the aim of addressing the research problem. Descriptive research which describes the characteristics of a population or a phenomenon being studied is appropriate for the study (Doody and Noonan (2016). The research strategy adopted for the study was a case study approach, this kind of study is used to investigate the phenomena within its real-life contest. The study used Prime Infrastructure and Engineering Services Ghana Limited as its case study. The study adopted the quantitative form of research for the answering of its research questions. The study adopted quantitative research approach to identify the causes and effects of projects delay. The study also used quantitative research approach to establish the results from examining the effects of project delay in the field of construction (Fusch and Ness, 2015).

The study used Prime infrastructure and Engineering Ghana Limited as its population. The populace of the study is projected at sixty. The study gathered data from staff of Prime Infrastructure and Engineering Services Ghana Limited. The Primary sources of data was used for the study. Questionnaire were shared across 60 staff of prime but could only get 50 respondents at the time of colleting the questionnaire because most of the team were out of the 
office. The sampling of answers from Questionnaire was the instrument used to gather the data for the study. A questionnaire contains series of questions to be administered to respondents with the aim of gathering data for the study. The questionnaire: comprising of 5-point likert scale questions was distributed across the sample size. Questionnaires gives the respondents the liberty to answer the questions. In order to whip up the interest of the respondents, the questionnaires were concise hence respondents had less challenge in understating the usage of it. The researcher was able to draw conclusion from the study based on data collection.

According to Creswell (2014), transforming data into meaningful information with the sole aim of undertaking decision is referred to as data analysis and presentation. As part of the processes involved in data analysis, the data collected was coded. The data was analyzed with the aid of Statistical tool known as Social Package for Social Science. The results of the study were presented in the form of percentages, mean, range, standard deviation and narrations.

\section{Discussion}

The responses on the causes of project delay are shown in the table labelled 4.6 below.

Table 1. Causes of project delay

\section{Descriptive Statistics}

\begin{tabular}{|l|c|c|c|c|c|}
\hline Description & $\mathrm{N}$ & Minimum & Maximum & Mean & Std. Deviation \\
\hline Unreasonable project Scope & 50 & 1 & 2 & 1.22 & .418 \\
\hline Inadequate Planning & 50 & 1 & 3 & 1.42 & .575 \\
\hline Lack of risk assessment & 50 & 1 & 5 & 2.30 & 1.055 \\
\hline Lack of resources & 50 & 1 & 2 & 1.18 & .388 \\
\hline Over ambitious & 50 & 1 & 3 & 1.32 & .513 \\
\hline Lack of task & 50 & 1 & 4 & 1.88 & .824 \\
\hline Design delay & 50 & 1 & 4 & 1.62 & .697 \\
\hline Valid N (listwise) & 50 & & & & \\
\hline
\end{tabular}

Source: Author's Survey, January 2020

As presented in table 1 above, unreasonable project scope ranged from 1, referring to strongly agree to 2 agree implying agree. 1.22 mean value with 0.418 deviation from the mean implies that the participants agreed unreasonable project scope was a cause of project delay. This finding is in line with Adams et al. (2017), who agreed that unreasonable project scope was one of the causes of project delay. As presented in table 4.6 above, inadequate planning ranged from 1, referring to strongly agree to 3 implying undecideds. 1.42 mean value with 0.575 deviation from the mean implies that the participants agreed inadequate planning was a cause of project 
delay. This finding is in line with Amoatey et al. (2015), who agreed that inadequate planning was one of the causes of project delay. As presented in table 4.6 above, lack of risk management ranged from 1, referring to strongly agree to 5 implying strongly agree. 2.30 mean value with 1.055 deviation from the mean implies that the participants agreed that lack of risk management was one of the causes of project delay. This finding is in line with. Ballesteros-Perez et al. (2015), who agreed that lack of risk management was one of the causes of project delay. As presented in table 4.6 above, lack of resources and labour productivity ranged from 1, referring to strongly agree to 5 implying strongly agree. 2.30 mean value with 1.055 deviation from the mean implies that the participants agreed that lack of resources and labour productivity was one of the causes of project delay. This finding is in line of Bagaya and Song (2016), who agreed that lack of resources and labour productivity was one of the causes of project delay. As presented in table 4.6 above, over-ambitious and incorrect task assessment ranged from 1, referring to strongly agree to 3 implying undecideds. 1.3200 mean value with 0.513 deviation from the mean implies that the participants agreed over-ambitious and incorrect task assessment was one of the causes of project delay.

This finding is in line of Ballesteros-Perez et al. (2015) who agreed that over-ambitious and incorrect task assessment was one of the causes of project delay. As presented in table 4.6 above, lack of task clarity ranged from 1 , referring to strongly agree to 4 implying disagree. 1.3200 mean value with 0.513 deviation from the mean implies that the participants agreed lack of task clarity was one of the causes of project delay. This finding is in line of Amoatey et al. (2015), who agreed that lack of task clarity was one of the causes of project delay.

As presented in table 4.6 above, design delays and approval of drawings ranged from 1, referring to strongly agree to 5 implying strongly agree. 1.6200 mean value with 0.697 deviation from the mean implies that the participants agreed design delays and approval of drawings was one of the causes of project delay. This finding is in line of Adams et al. (2017), who agreed that design delays and approval of drawings was one of the causes of project delay.

\section{Construction Stages which affect construction Delay}

The responses on Construction Stages which affect construction Delay are shown in table 4.7 below.

Table 2. Responses on Construction Stages which affect construction Delay

\section{Descriptive Statistics}

\begin{tabular}{|l|c|c|c|c|c|}
\hline Description & $\mathrm{N}$ & Minimum & Maximum & Mean & Std. Deviation \\
\hline Feasibility Study & 50 & 1 & 2 & 1.18 & .388 \\
\hline Design Phrase & 50 & 1 & 2 & 1.34 & .479 \\
\hline Contracting phrase & 50 & 1 & 4 & 1.54 & .676 \\
\hline Implementation phase & 50 & 1 & 2 & 1.18 & .388 \\
\hline Delivery Phrase & 50 & 1 & 3 & 1.32 & .513 \\
\hline
\end{tabular}




\begin{tabular}{|l|c|c|c|c|c|}
\hline Investment Phrase & 50 & 1 & 3 & 1.56 & .611 \\
\hline Valid N (listwise) & 50 & & & & \\
\hline
\end{tabular}

Source: Authors' survey, (2020)

As presented in table 2 above, feasibility study ranged from 1, referring to strongly agree to 2 agree implying agree. 1.18 mean value with 0.388 deviation from the mean implies that the participants agreed feasibility study was a Construction Stages which affect construction Delay. This finding is in line of Adams et al. (2017), who agreed that feasibility study was a Construction Stages which affect construction Delay. As presented in table 4.7 above, design phrase ranged from 1, referring to strongly agree to 2 agree implying agree. 1.34 mean value with 0.479 deviation from the mean implies that the participants agreed design phrase was a Construction Stages which affect construction Delay. This finding is in line of Adams et al. (2017), who agreed that design phrase was a Construction Stages which affect construction Delay. As presented in table 4.7 above, contracting phrase ranged from 1, referring to strongly agree to 4 disagree, implying disagree. 1.54 mean value with 0.676 deviation from the mean implies that the participants agreed contracting phrase was a Construction Stages which affect construction Delay. This finding is in line of Adams et al. (2017), who agreed that contracting phrase was a Construction Stages which affect construction Delay. As presented in table 4.7 above, implementation phrase ranged from 1, referring to strongly agree to 2 agree, implying agree. 1.18 mean value with 0.388 deviation from the mean implies that the participants agreed implementation phrase was a Construction Stages which affect construction Delay. This finding is in line of Adams et al. (2017), who agreed that implementation phrase was a Construction Stages which affect construction Delay.

As presented in table 4.7 above, delivery phrase ranged from 1, referring to strongly agree to 3 undecideds, implying undecided. 1.32 mean value with 0.513 deviation from the mean implies that the participants agreed delivery phrase was a Construction Stages which affect construction Delay. This finding is in line of Adams et al. (2017), who agreed that delivery phrase was a Construction Stages which affect construction Delay. As presented in table 4.7 above, investment phrase ranged from 1, referring to strongly agree to 3 undecideds, implying undecided. 1.56 mean value with 0.611 deviation from the mean implies that the participants agreed investment phrase was a Construction Stages which affect construction Delay. This finding is in line of Adams et al. (2017), who agreed that investment phrase was a Construction Stages which affect construction Delay.

Table 3. Responses of project delay effects

\section{Descriptive Statistics}

\begin{tabular}{|l|c|c|c|c|c|}
\hline & $\mathrm{N}$ & Minimum & Maximum & Mean & Std. Deviation \\
\hline Total Abandonment & 50 & 1 & 5 & 1.86 & .948 \\
\hline Time overrun & 50 & 1 & 2 & 1.12 & .328 \\
\hline Cost over & 50 & 1 & 3 & 1.28 & .497 \\
\hline
\end{tabular}




\begin{tabular}{|l|c|c|c|c|c|}
\hline Litigation & 50 & 1 & 4 & 1.84 & .842 \\
\hline Valid N (listwise) & 50 & & & & \\
\hline
\end{tabular}

Source: Authors' survey, 2020

As presented in table 3 above, Total Abandonment ranged from 1, referring to strongly agree to 5 strongly disagree, implying strongly disagree. 1.86 mean value with 0.948 deviation from the mean implies that the participants agreed Total Abandonment was an effect of Delay. This finding is in line of Adams et al. (2017), who agreed Total Abandonment was an effect of delay. As presented in table 4.8 above, Time overrun ranged from 1, referring to strongly agree to 2 agree, implying agree. 1.12 mean value with 0.328 deviation from the mean implies that the participants agreed Time overrun was an effect of Delay. This finding is in line of Adams et al. (2017), who agreed Time overrun was an effect of delay. As presented in table 4.8 above, Cost overrun ranged from 1, referring to strongly agree to 3 undecideds, implying undecided. 1.12 mean value with 0.328 deviation from the mean implies that the participants agreed cost overrun was an effect of Delay. This finding is in line of Adams et al. (2017), who agreed cost overrun was an effect of delay. As presented in table 4.8 above, litigation ranged from 1, referring to strongly agree to 4 disagree, implying disagree. 1.84 mean value with 0.842 deviation from the mean implies that the participants agreed litigation was an effect of Delay. This finding is in line of Adams et al. (2017), who agreed litigation was an effect of delay.

Table 4. Model Summary

\begin{tabular}{|c|c|c|c|c|}
\hline Model & $\mathrm{R}$ & R Square & $\begin{array}{c}\text { Adjusted R } \\
\text { Square }\end{array}$ & Std. Error of the Estimate \\
\hline 1 & $.824^{\mathrm{a}}$ & .679 & .665 & .23050 \\
\hline
\end{tabular}

a. Predictors: (Constant), Causes, Construction Stages

From table 3, $0.679 \mathrm{R}$-square is a measure of quality prediction for the dependent variable, implying strong correlation between variables. $32.1 \%$ predicts the proportion of variance of the variables.

\section{Variable Analysis}

Table 5. ANOVA

\begin{tabular}{|c|c|c|c|c|c|c|}
\hline \multicolumn{2}{|c|}{ Model } & Sum of Squares & df & Mean Square & F & Sig. \\
\hline \multirow{3}{*}{1} & Regression & 5.284 & 2 & 2.642 & 49.726 & $.000^{\mathrm{b}}$ \\
\cline { 2 - 7 } & Residual & 2.497 & 47 & .053 & & \\
\cline { 2 - 7 } & Total & 7.781 & 49 & & & \\
\hline
\end{tabular}

a. Dependent Variable: Effect of construction delay

b. Predictors: (Constant), Causes, Construction stages 
Table 5 presents the responses on the fitness of the model. From the table the model good fit for the data. From the table F-value is 49.726 and statistically significant at 0.00 , there is a significant relationship between the predictors and the dependent variable.

Table 6. Coefficients

\begin{tabular}{|c|c|c|c|c|c|c|}
\hline \multicolumn{2}{|c|}{ Model } & \multicolumn{2}{|l|}{ Unstandardized Coefficients } & $\begin{array}{c}\text { Standardized } \\
\text { Coefficients }\end{array}$ & $\mathrm{t}$ & Sig. \\
\cline { 2 - 7 } & B & Std. Error & Beta & & \\
\hline \multirow{3}{*}{1} & (Constant) & .210 & .139 & & 1.517 & .136 \\
\cline { 2 - 7 } & Causes & .869 & .131 & .768 & 6.613 & .000 \\
\cline { 2 - 7 } & Con. Stage & .080 & .121 & .077 & .660 & .512 \\
\hline
\end{tabular}

a. Dependent Variable: Effects of construction Delay

From the table 6 above co-efficient of 0.210 with 0.138 significant level indicates that the constant is not significant. Co-efficient of 0.869 with 0.00 significant level indicates that the causes are significant. This implies that there is a positive relationship between causes of construction delay and the effects of construction delay. Co-efficient of 0.080 with 0.512 insignificant level indicates that the construction stages are significant. This implies that there is no relationship between causes of construction stages and the effects of construction delay.

The regression model will be fitted as follows:

Effect of project delay $=.210+.869 \mathrm{X}_{1}+.080 \mathrm{X}_{2}$

$\mathrm{X}_{1}=$ causes

$\mathrm{X}_{2}=$ construction stages

\section{Suggested measures to management project delay}

Most of the respondents agreed that project management principles were some of the measures to prevent project delay. The principles of project management are the fundamental rules that should be followed for the successful management of project delay. This finding is in line with Ahmed et al. (2003) who recommended that, project management principles were some of the measures to prevent project delay.

Greater percentage of respondent agreed that managing ineffective planning and scheduling were some of the measures to prevent project delay. This finding is in line with Burke (2013) research finding which recommended that, managing ineffective planning and scheduling were some of the measures to manage project delay. The greater number of respondents agreed that Managing staff qualification, skills and experience were some of the measures to manage project delay. To ensure efficient management of projects, there is the need to manage staff qualification, skills and experience. As part of measures to ensure efficient management of staff qualification, there should screening to ensure people who possess the requisite skills and competencies are assigned the specific tasks. 
Asian Journal of Applied Science and Technology

Volume 4, Issue 3, Pages 129-144, July-September 2020

This finding is in line with Burke (2013) research finding which recommended that, managing poor qualifications, skills and experience of the contractors' staff were some of the measures to manage project delay.

Many of the respondents agreed that Change order management was a measure to manage project delay. In order to minimize unwanted delay in construction projects for clients, there is the need to change orders during construction by either adding or deleting some activities (Kallantzis et al, 2007). Many of the respondents agreed that Delay rectification was a measure to manage project delay. This finding is in line with Kallantzis et al. (2007) who identified ways of rectifying delay in construction projects

\section{Conclusion}

The study identified the Causes of Project Delay as unreasonable project scope; inadequate planning; Lack of risk management system; Lack of resources and labour productivity; Over-ambitious and incorrect task assessment; and lack of task clarity. The study identified the Construction Stages which affect construction Delay as feasibility study phrase; the design phrase; contracting phrase; implementing phrase; delivery phrase and investment (operation) phrase. Effects of project Delay were identified as Total Abandonment, Time overrun, cost overrun and litigation. The study also established a positive relationship between the causes of project delay and the effect of project delay. Based on the above-mentioned findings, the following recommendations were made.

Project management principles should be put in place to minimize project delay. Managing projects involve organizing; planning; securing; controlling resources for specific goal achievement. Managing projects involves fundamental rules which are observed for managing projects successfully. There should be effective management of planning and scheduling. Planning paves way for efficient management of resources. Planning provides a means of processes together. It also maximises opportunity for reliable production. As part of measures to prevent project delay planning and scheduling must managed effectively. There should be effective. As part of measures to ensure efficient management of staff qualification potential staff should possess the requisite qualification, skills, and experience before they are recruited into the entity.

There should be effective Management of change order during construction. To minimize unwanted delay, there should be Change orders management which involves addition and deletion of project scopes. Addition and deletion of project scopes involve cost and times overrun. There should be delay rectification for effective management of construction delay. Overtime working and working through the shift systems as measure to ensure Delay rectification. Ways of delay rectification include reallocation of resources, double checking dependencies etc.

\footnotetext{
References

Adam, A., Josephson, P.-E.B. and Lindahl, G. (2017), "Aggregation of factors causing cost overruns and time delays in large public construction projects: trends and implications", Engineering, Construction and Architectural Management, Vol. 24 No. 3, pp. 393-406.

Agyekum-Mensah, G. and Knight, A.D. (2017), “The professionals' perspective on the causes of project delay in the construction industry", Engineering, Construction and Architectural Management, Vol. 24 No. 5, pp. 828-841.
} 
Asian Journal of Applied Science and Technology Volume 4, Issue 3, Pages 129-144, July-September 2020

Amoatey, C.T., Ameyaw, Y.A., Adaku, E. and Famiyeh, S. (2015), "Analysing delay causes and effects in Ghanaian state housing construction projects", International Journal of Managing Projects in Business, Vol. 8 No. 1, pp. 198-214.

Amoatey, C.T., Ameyaw, Y.A., Adaku, E. and Famiyeh, S. (2015), "Analysing delay causes and effects in Ghanaian state housing construction projects", International Journal of Managing Projects in Business, Vol. 8 No. 1, pp. 198-214.

Ansah, R.H. and Sorooshian, S. (2018), "4P delays in project management", Engineering, Construction and Architectural Management, Vol. 25 No. 1, pp. 62-76.

Al-Agele H. K., and Al-Hassan, A. J., The Reasons of Costs Deviation in the Iraqi Construction Projects - Field Assessment, Applied Research Journal, 2016, 2(5), p. 228-237.

Asiedu, R.O. and Alfen, H.W. (2016), "Understanding the underlying reasons behind time overruns of government building projects in Ghana”, KSCE Journal of Civil Engineering, Vol. 20 No. 6, pp. 2103-2111.

Aziz, R.F.; Abdel-Hakam, A.A. Exploring delay causes of road construction projects in Egypt. Alex. Eng. J.2016, 55, 1515-1539. [CrossRef]

Ballesteros-Pérez, P., Del Campo-Hitschfeld, M.L., González-Naranjo, M.A. and González-Cruz, M.C. (2015), "Climate and construction delays: case study in Chile", Engineering, Construction and Architectural Management, Vol. 22 No. 6, pp. 596-621.

Bagaya, O. and Song, J. (2016), "Empirical study of factors influencing schedule delays of public construction projects in Burkina Faso", Journal of Management in Engineering, Vol. 32 No. 5.

Bakr, G. A., Causes of Delay in Public Construction Projects in Iraq, Jordan Journal of Civil Engineering, 2015, 9(2), p. 149-162.

Bentil, N. L. (2014, March 6). Contractors working on two major road projects which are part of the_Gang of Six roads have abandoned the project site for lack of payment. Abandoned the project site for lack of payment "graphic news".

Creswell J (2012) Research design. Qualitative, quantitative and mixed methods approach (2nd edn). Thousand Oaks, CA: Sage.

DeVaus, D. A., 2002. Surveys in Social Science Research. 5 ed. London: Roulega.

Eizakshiri, F., Chan, P.W. and Emsley, M.W. (2015), "Where is intentionality in studying project delays?", International Journal of Managing Projects in Business, Vol. 8 No. 2, pp. 349-367.

Guo, S.; Zhang, P.; Yang, J. System dynamics model based on evolutionary game theory for quality supervision among construction stakeholders. J. Civ. Eng. Manag. 2018, 24, 318-330. [CrossRef] 
Asian Journal of Applied Science and Technology Volume 4, Issue 3, Pages 129-144, July-September 2020

Hosseini, M.R., Maghrebi, M., Akbarnezhad, A., Martek, I. and Arashpour, M. (2018), "Analysis of citation networks in building information modeling research", Journal of Construction Engineering and Management, Vol. 144 No. 8.

Jaber, F. K., Establishing Risk Management Factors for Construction Projects in Iraq, International Journal of Advanced Research in Engineering and Technology, 2015, 6(1), p. 35-48.

Kamandang, Z.R., J.-B. Yang, and I. Wijatmiko. An Empirical Study on Analyzing Schedule

Delays of Construction Project in Indonesia. in ISARC. Proceedings of the International

Symposium on Automation and Robotics in Construction. 2017. Vilnius Gediminas Technical

University, Department of Construction Economics \& Property.

Kim, S.-Y., Tuan, K.N. and Luu, V.T. (2016), "Delay factor analysis for hospital projects in Vietnam”, KSCE Journal of Civil Engineering, Vol. 20 No. 2, pp. 519-529.

Kumar, D. R. (2016). Causes and effects of delays in indian construction projects. International

Research Journal of Engineering and Technology (IRJET), 3(4), 1831-1837.

Kuşakçı, A. O., Ayvaz, B., \& Bejtagic, E. (2017). An analysis of causes and effects of delays

in construction projects in Libyan oil industry. Karaelmas Science and Engineering Journal,

$7(1), 274-282$.

Larsen, J.K., Shen, G.Q., Lindhard, Sø., M. and Brunoe, T.D. (2016), "Factors affecting schedule delay, cost overrun, and quality level in public construction projects", Journal of Management in

Engineering, Vol. 32 No. 1.

Mahamid, I. (2017), "Analysis of schedule deviations in road construction projects and the effects of project physical characteristics", Journal of Financial Management of Property and Construction, Vol. 22 No. 2, pp. 192-210.

Mohammed, F. H., Causes of Delays in Construction Projects in Kurdistan Region of Iraq, 2015, Master thesis, Portsmouth, University of Portsmouth. England: University of Portsmouth.

Mpofu, B., Ochieng, E.G., Moobela, C. and Pretorius, A. (2017), "Profiling causative factors leading to construction project delays in the United Arab Emirates", Engineering, Construction and Architectural Management, Vol. 24 No. 2, pp. 346-376.

Nguyen, L.H. Relationships between Critical Factors Related to Team Behaviors and Client Satisfaction in Construction Project Organizations. J. Constr. Eng. Manag. 2019, 145, 04019002. [CrossRef]

Oyegoke, A.S. and Al Kiyumi, N. (2017), "The causes, impacts and mitigations of delay in megaprojects in the Sultanate of Oman", Journal of Financial Management of Property and Construction, Vol. 22 No. 3, pp. 286-302. 
Owolabi James D, Olusanya etc.., (2014) "Causes and Effect of delay on project construction delivery time". International Journal of Education and Research.

Polit \& Hungler, 1995. Graduate Research: A Guide for Students in the Sciences. 2 ed. New York: Plenum, Press Ruqaishi, M. and Bashir, H.A. (2015), "Causes of delay in construction projects in the oil and gas industry in the gulf cooperation council countries: a case study", Journal of Management in

Engineering, Vol. 31 No. 3 .

Sezgin, A. G., \& Aşarkaya, A. (2017). Construction sector. Department of Economic Research

Report, İş Bank, İstanbul. (in Turkish)

Su, Y.; Lucko, G.; Thompson, R.C., Jr. Application of Voting Theory to the Float Ownership Problem. JCEM 2018, 144, 04017094. [CrossRef]

Tafazzoli, M. S., \& Shrestha, P. P. (2017). Investigating causes of delay in U.S. construction projects. In Proc., 53rd ASC Annual International Conference (pp. 611-621).

Tripathi, K.K.; Jha, K.N. Determining Success Factors for a Construction Organization: A Structural Equation Modeling Approach. J. Manag. Eng. 2018, 34, 04017050. [CrossRef]

Wu, G.; Wang, H.; Chang, R. A Decision Model Assessing the Owner and Contractor's Conflict Behaviors in Construction Projects. Adv. Civ. Eng. 2018, 2018, 1347914. [CrossRef]

Venkateswaran, C.B. and Murugasan, R. (2017), "Time delay and cost overrun of road over bridge (ROB) construction projects in India”, Journal of Construction in Developing Countries, Vol. 22 No. 1, pp. 79-96. 